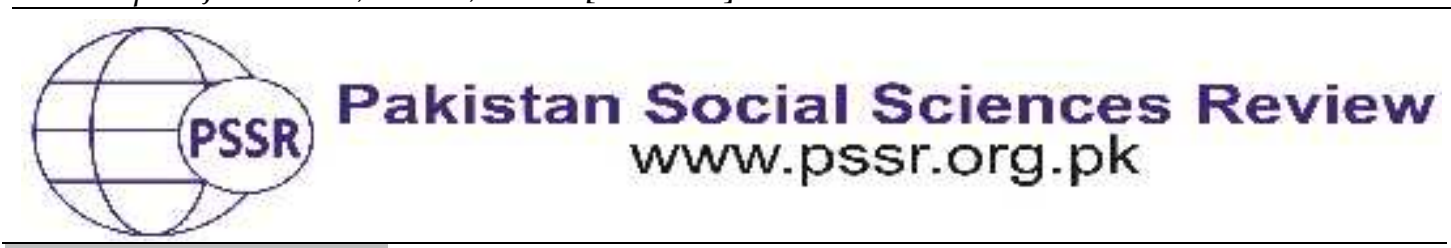

RESEARCH PAPER

\title{
Students and COVID-19: A Phenomenological Study of Undergraduate Students in Pakistan
}

\author{
Dr. Umi Lela ${ }^{1}$ Sana Rehman ${ }^{2}$ Dr. Muhammad Latif ${ }^{3}$
}

1. Head of Department, Humanities and Social Sciences, GIFT University, Gujranwala, Punjab, Pakistan

2. Lecturer, Humanities and Social Sciences, GIFT University, Gujranwala, Punjab, Pakistan

3. Assistant Professor/In-charge Department of Education, GC Women University Sialkot, Punjab, Pakistan

\begin{tabular}{|c|c|}
\hline PAPE & ABSTRACT \\
\hline $\begin{array}{l}\text { ed: } \\
\text { y } 11,2021 \\
\text { d: } \\
2021 \\
2021\end{array}$ & $\begin{array}{l}\text { The current study aimed at investigating the student reaction } \\
\text { towards COVID-19. The pandemic affected all areas of human } \\
\text { functioning; in the particular education system has undergone a } \\
\text { significant transformation. Students experienced significant } \\
\text { emotional turmoil during educational transformation. Therefore }\end{array}$ \\
\hline $\begin{array}{l}\text { rds: } \\
19 \text {, } \\
\text { Education, } \\
\text { enologica } \\
\text { ine, }\end{array}$ & $\begin{array}{l}\text { It is important to investigate student s reaction during COVID- } \\
\text { 19. Using a convenient sampling technique, } 120 \text { undergraduate } \\
\text { students of Gujranwala Universities have been recruited. The } \\
\text { students were interviewed using a self-indigenous interview } \\
\text { guide. Multiple themes have been generated through a } \\
\text { phenomenological approach. The findings of the study } \\
\text { provided an interesting but alarming picture of students }\end{array}$ \\
\hline $\begin{array}{l}\text { *Corresponding } \\
\text { Author }\end{array}$ & $\begin{array}{l}\text { responses. The reactions of students have been summarized into } \\
\text { diverse themes such as negative outlook towards life, mental } \\
\text { health problems, and unproductive activities during quarantine }\end{array}$ \\
\hline $\begin{array}{l}\text { ssc.hod@gift.edu } \\
\text {.pk }\end{array}$ & $\begin{array}{l}\text { apd apprehensions towards education. The findings should be } \\
\text { ddressed in terms of counseling for mental health issues, and } \\
\text { evising an online education policy to meet students need and } \\
\text { irter their fears. }\end{array}$ \\
\hline
\end{tabular}

\section{Introduction}

Coronavirus disease (COVID-19) originated at Wuhan city and spread rapidly to the 72 countries (Li et al., 2020). Like all other countries, Pakistan emerged as a prominent epicenter of the looming pandemic. The Pakistani masses were not ready to take the burden of infectious diseases (Khan et al., 2020). As a result, all area of human life affected adversely, in particular, the academic life and living standards of students faced significant losses (Fiorillo \& Gorwood, 2020: Waris, Atta, Ali, Asmat, \&Baset, 2020). To break the chain of COVID-19 two type of rule have been 
emerged i.e. quarantine and isolation. Quarantine is effective to save human lives, but it has affected student's academic as well as personal life on a very high scale (Huremovic, 2019).

At a personal level, the limited social activities and excessive screen time bring about psychological disturbance among students. Pakistan is a collectivistic culture, where the personal life of the students is controlled by the family peers and society overall. Surprisingly, the advance trends of the western world are prevailing in Pakistan; as a result, the students are spending more independent lives (Mukhtar, 2020). The choices for spending quarantine time are limited to social media, television and movies ( $\mathrm{Li}$, Wang, Xue, Zhao \& Zhu, 2020). In such circumstances, personal development is hard to maintain (Keles, McCrea, Grealish, 2020). Furthermore, the literature suggested that excessive use of social media is consistent with a psychological problem such as anxiety, depression, personality disorder and hallucinations (Gao et. al. 2020).

At the academic level, the long semester break has caused apprehension about academic and career life. The academic break not only developed the fear and apprehension about the future but also caused significant mental health issues (Shigemura, Ursano, Morganstein, Kurosawa, Benedek, 2020). Again the academic break is alarmingly increasing the ratio of watching TV and using social media. Social media broadcast misinformation which is obnoxious for human mental as well as physical health (Bontcheva, Gorrell, Wessels, 2013). Hence, it is imperative to engage students in academic and productive activities. Consequently, to resolve the academic issues the Higher Education Commission and university authorities are collaboratively taking initiative to develop online education. The online education is a very crucial step for the academic growth of the student (Chiodini, 2020). Indeed the step towards online education would be very helpful to engage students in productive activities and in decreasing the mental or psychological issues (Zhou, Huang, Cheng, \& Xiao, 2020: Rehman \& Lela, 2021). Unfortunately, many factors may cause hindrance in promoting online education such as financial crises, technological limitation and untrained staff.

As students are the central part of the online education system therefore, it would be interesting to investigate the student's reaction during the critical time of pandemic and how they see the online education system. Currently, literature is lacking in this regard, therefore the current study would be a significant contribution in literature. Therefore the current study was designed to investigate the student's reaction towards COVID-19 pandemic.

\section{Material and Methods}

\section{Research Design}

The current study used Collaizi's phenomenological for qualitative analysis of student's response. Collaizai method helps to investigate the experience of 
participants in a shared manner rather than individual characteristic. This scientific approach provides the authentic pattern of the participant's experiences.

\section{Study Subjects}

Around 120 participants of a university have been recruited using purposeful sampling technique from July 1, 2020, to May 3, 2020. The inclusion criteria (1) the undergraduate students studying at University (2) volunteers who participated in the study.

\section{Interview Outline}

The interview outline was determined by consulting literature and seeking experts' opinion. The main interview question posed to participants are (a) As a student, share your thoughts/feelings about COVID-19? (B) What are your present thoughts about education? (C) 4 . What do you foresee online education? (D) 5. How are you spending your socially distant time?

\section{Data Collection}

The data was collected considering the current needs of the time. The advanced online system was used to obtain the responses of the students.

\section{Data Analysis}

The recorded responses were transcribed and analyzed through Collaizai phenomenological method. Three researchers independently reviewed the interview material, summarized, extracted the meaningful statement and generated the themes. The conflicting opinion was discussed by a group of researchers and a final list of themes was recorded.

\section{Ethical Review}

All the participants signed the informed consent. The authors claimed that they will not violet the ethical rules in terms of misconduct, plagiarism, falsification, data fabrication and repeated publication.

\section{Results and Discussion}

The researcher explored the student reaction towards COVID-19 pandemic using a phenomenological approach. Four themes were found that are presented and summarized below. The exemplar quiet for each theme has been added in table 2 . 
Table 1

The following table indicates the demographical characteristics of the participants.

\begin{tabular}{cccc}
\hline Characteristics & & N (\%) or mean \pm SD & Median \\
\hline Gender & Male & $66(55 \%)$ & \\
\hline Age & Female & $54(45 \%)$ & $22(20-25)$ \\
\hline Area & & $22.15 \pm 1.52$ & \\
\hline & Urban & $48(40 \%)$ & \\
\hline Academic Semester & Rural & $72(60 \%)$ & \\
\hline & $1^{\text {st }}$ & $6(5 \%)$ & \\
\hline & $2^{\text {nd }}$ & $14(12 \%)$ \\
\hline & $3^{\text {rd }}$ & $30(25 \%)$ & \\
\hline & $4^{\text {th }}$ & $70(58 \%)$ & \\
\hline
\end{tabular}

Theme 1: Significant negative feelings and emotions

In response to the question "share your feeling and thought about COVID19, the student's reactions were observed to be interesting but alarming. Multiple variations in responses of students have been observed. Their feelings and thoughts of the students have been divided into three subthemes such as religious concern, psychological burden and social disturbance. According to some $(n=73)$ participants, they view COVID-19 as a punishment from God and can only be cured by Almighty. According to some other $(n=47)$ participants, they feel COVID-19 as a threat to their lives and causing psychological disturbance such as anxiety, fear, depression and phobias. Very few participants $(n=20)$ defined COVID-19 in terms of social isolation. According to them COVID-19 means limited outdoor activities and disturbed social.

\section{Theme 2: Quarantine}

The variation in responses has been observed in three subdomains i.e. psychological manifestation, social media and productive activity. Most students $(n=45)$ reported that they are spending their quarantine time on social media. The chatting and watching movies were the only hobby during the quarantine. Furthermore, they also showed satisfaction with this routine. Around $(n=42)$ students manifested their frustration towards quarantine time. It was observed that quarantine time developing much psychological disturbance such as anxiety depression, stress and cluster phobia. A very few participants $(n=18)$ reported productive activities during quarantine such as spending time with family, reciting Holy Quran and reading books.

\section{Theme 3: Online Education}

The reaction of the students towards online education system was quite interesting. Maximum participant $(n=92)$ reported online education best way to continue their studies in the critical time of the pandemic. Most of the students 
showed their concern for educational degrees, therefore they were eager to continue online education. Furthermore, for some student online education was a novel and exciting. It was also observed that student belongs to a distant area were also satisfied with the distance learning program as they don't have to waste enough time for travelling or fares. While $(n=28)$ participants responses were in favour of the traditional education system. Students reported multiple reasons for their dislikeness towards online education systems such as technological unfamiliarity, low education quality and financial cries.

\section{Theme 4: Psychological Issues}

All of the participants reported significant negative emotions and feelings. When the participants were asked to share their feelings and thoughts about COVID-19, the variation of their responses was observed into three sub domains. The three sub domains were a religious concern, psychological burden and social distancing. According to the majority of the participant, the deadly disease of COVID-19 has a religious root. The fundamental cause of COVID-19 is religious disobedience. According to $(\mathrm{n}=98)$ participants view COVID-19 as a psychological burden. The fear, anxiety, depression and frustration were the common psychological symptoms they were experiencing. Around (n-22) participants reported COVID-19 a unique disease which has affected all area of human functioning. These participants generally elaborated the disease with social distancing concept but the negative feeling can also be observed.

\section{Table 2}

The following table depicted the themes and subthemes of the data

\begin{tabular}{|c|c|c|}
\hline Theme & Sub-themes & Quotations \\
\hline $\begin{array}{l}\text { Significant } \\
\text { negative } \\
\text { apprehensions } \\
\text { towards life }\end{array}$ & $\begin{array}{l}\text { Religious concerns, } \\
\text { Punishment from } \\
\text { God, Result of Our } \\
\text { Sin, Test from God }\end{array}$ & $\begin{array}{l}\text { "It might b a punishment given by Allah to } \\
\text { humanity come to the right path" } \\
\text { " It is a test from God people should } \\
\text { understand it" } \\
\text { "This is a break from ALLAH, you may } \\
\text { have an idea our ozone layer is getting } \\
\text { better due to traffic-stopping' } \\
\text { "It's the very stressful situation may Allah } \\
\text { forgive our sins and protect our world, } \\
\text { family, friends" } \\
\text { "It is a really harmful disease and came } \\
\text { from ALLAH so we believe in ALLAH and } \\
\text { stay home because precaution is better than } \\
\text { cure" } \\
\text { "It's the result of our sins." } \\
\text { "Its a message by Allah to us that } \\
\text { everything in this entire universe is a bubble } \\
\text { of water" } \\
\text { " We should take a look on our daily affairs }\end{array}$ \\
\hline
\end{tabular}


and then ask to ourselves that its the result of our sins."

\begin{tabular}{|c|c|c|}
\hline & $\begin{array}{l}\text { Psychological } \\
\text { burden, } \\
\text { Depression,, } \\
\text { anxiety, } \\
\text { anxiousness, fear }\end{array}$ & $\begin{array}{l}\text { "Bcz of Covid-19, many of us are depressed } \\
\text { at homes with no outing and no proper } \\
\text { interaction with our friends" } \\
\text { "It seems like horror movie" } \\
\text { "I am too much afraid of this virus. It has } \\
\text { affected every field of our life." } \\
\text { "I feel very frustrated and worried" } \\
\text { "Usually, in normal days I don't have } \\
\text { anxiety but this make me so depressed" } \\
\text { "By watching the news we shouldn't get } \\
\text { scared of it in fact fight for it and stay at } \\
\text { home" } \\
\text { "Future seems dark" } \\
\text { "I feel we all will die. Fear of death } \\
\text { sometimes makes me freighted" }\end{array}$ \\
\hline & Social Isolation & $\begin{array}{l}\text { 'It's a hard time for all of us. But a good time } \\
\text { to spend time with family and with our } \\
\text { self". } \\
\text { "Coronavirus really affected our daily life } \\
\text { routine, our studies But we hoped due to } \\
\text { this locked down we will save in our } \\
\text { homes" } \\
\text { "It's too much dangerous all people become } \\
\text { scared from it's it's effect all works are close } \\
\text { no social activities no social mingle make } \\
\text { people aggressive and depressed" } \\
\text { "ughhhh kindly over this I can't stay at } \\
\text { home anymore" } \\
\text { "I think its pandemic that is affecting people } \\
\text { globally and has many bad aspects on our } \\
\text { daily life routines as well as our long term } \\
\text { plans. But I think it is also a good time to } \\
\text { reflect on our lives, to be better versions of } \\
\text { ourselves. Utilize this time for our } \\
\text { betterment". }\end{array}$ \\
\hline $\begin{array}{l}\text { Academic } \\
\text { Apprehension }\end{array}$ & $\begin{array}{l}\text { Uncertainty about } \\
\text { future, waste of } \\
\text { time, barrier in } \\
\text { carrier } \\
\text { development, } \\
\text { financial issues }\end{array}$ & $\begin{array}{l}\text { 'As a student, the future seems vague \& } \\
\text { uncertain due to COVID-19". } \\
\text { "The gap in education has wasted enough } \\
\text { time and there is no hope about how long it } \\
\text { would be" } \\
\text { The delay in education is also causing } \\
\text { hindrance in our career development as we } \\
\text { cannot pursue any job without degree" }\end{array}$ \\
\hline
\end{tabular}




\begin{tabular}{|c|c|c|}
\hline \multicolumn{3}{|l|}{ Quarantine } \\
\hline & Social Media & $\begin{array}{l}\text { "I'm spending most of my time social } \\
\text { media" } \\
\text { "I watch Netflix in my spare time" } \\
\text { "I watch movies as makes me feel good" } \\
\text { "Quarantine is the best time to live life with } \\
\text { our own will as I can watch maximum } \\
\text { movies, and free use of social media" }\end{array}$ \\
\hline & $\begin{array}{l}\text { Psychological } \\
\text { symptoms }\end{array}$ & $\begin{array}{l}\text { "During quarantine, I don't know how to } \\
\text { spend my time. most of the time I feel } \\
\text { isolation" } \\
\text { "I am frustrated due to limited outdoor } \\
\text { activity." } \\
\text { "My social life has become disturbed, } \\
\text { sometimes I feel depression" } \\
\text { "I feel agitated at home, soon I'll develop a } \\
\text { fear of close places" }\end{array}$ \\
\hline & $\begin{array}{l}\text { Productive } \\
\text { activities }\end{array}$ & $\begin{array}{l}\text { "I spend my time in Reciting Holy Quran" } \\
\text { "I'm taking online Quran Classes" } \\
\text { " Most of the time I prefer to read book" } \\
\text { I spend my time learning new cooking } \\
\text { recipes" } \\
\text { "I spend time with family as isolation is } \\
\text { hard for me" }\end{array}$ \\
\hline \multicolumn{3}{|l|}{$\begin{array}{l}\text { Online } \\
\text { Education }\end{array}$} \\
\hline & $\begin{array}{l}\text { Positive responses } \\
\text { Degree } \\
\text { Completion, saving } \\
\text { of time and money, } \\
\text { advancement, } \\
\text { financial barriers }\end{array}$ & $\begin{array}{l}\text { "Online education is a good step so that I } \\
\text { would be able to get my degree on time" } \\
\text { "something is better than nothing, at least } \\
\text { we will be in touch with studies" } \\
\text { "I think online education is far better than } \\
\text { the traditional one as travelling waste lots of } \\
\text { time" } \\
\text { "online education is good steps, I am } \\
\text { enthusiastic" } \\
\text { " during the quarantine time when parents } \\
\text { are not earning enough so how one can } \\
\text { afford online education?" }\end{array}$ \\
\hline & $\begin{array}{l}\text { Negative responses } \\
\text { Technological } \\
\text { barrier, } \\
\text { comprehension } \\
\text { issues, interaction } \\
\text { barrier }\end{array}$ & $\begin{array}{l}\text { "Online education is going to be a mess as } \\
\text { we are not much familiar with technology". } \\
\text { "The quality of education would be low" } \\
\text { "Trough online education we can get } \\
\text { degree's but not knowledge" } \\
\text { "It would be hard to understand lesson } \\
\text { through digital communication" }\end{array}$ \\
\hline
\end{tabular}


“Learning outcomes would below.

\section{Discussion}

The study explored the student reaction towards COVID-19 pandemic using a phenomenological approach. The findings of the study revealed the four basic themes: significant negative apprehensions towards life, academic apprehensions, online education and quarantine. The students reported significant negative apprehensions towards the COVID-19 epidemic, which were consistent with the previous studies.

The students view COVID -19 as a result of religious disobedience. According to them, the deadly viral disease indicates GOD's anger on the world. The religious beliefs on the Muslim communities are very prevalent as all-natural or human-made disaster considered a punishment from God or the result of our sins. Literature was found to be consistent with the current study findings as religious and culture beliefs were strongly correlated with previous infection outbreaks (Huremovic, 2019: Rehman, Muzammil \& Lela, 2020). Apart from religious disobedience, the students reported their feeling in terms of extreme fear, depression and anxiety for their survival. Previous studies also reported similar results as the fear for survival during such an outbreak is common which cause multiple mental health disorders (Shigemura et. al., 2020: Rehman \& Lela, 2020). A few students also shared their feeling towards COVID-19 a socially limited disease.

The current study findings revealed that the majority of students spend their quarantine time on social media. The most common activity of students found to be chatting and watching movies. The literature confirmed the results of the current study and also indicates the adverse effect of social media and movies on the mental health of students ((Keles, McCrea, Grealish, 2020: Gao et. al., 2020). Apart from this, a few students were spending their quarantine time in productive activities such as healthy time with family, books reading cooking and other positive activities. Surprisingly the students who spend time on social media and in productive activity found to have a better adjustment to the environment. In contrast, the students who are not indulging in any activity report more isolation feeling of distress and other psychological disturbances. The literature contradicts the findings of the current study and depicts the adverse impact of quarantine time on mental health (Brooks et al., 2020: Chatterjee, \& Chauhan, 2020).

The student's reaction to education was found to be problematic. As the majority of the students were apprehensive about their academic as well as career life. Quarantine is consistent with apprehension towards multiple areas of life (Brooks et al., 2020)

As far as online education is concerned, students stated a diverse response. Around half of the students were enthusiastic about online education. The reason for their excitement for online education found to be educational continuity, 
technological advancement and saving of time. In contrast, many students manifested their dislikes towards online education system as according to them it is a barrier in the effective education system. Furthermore, students showed their concern for the financial barrier in online education. The literature is enriched with the studies supported the online education system in the critical time of infection disease and outbreak (Chiodini, 2020: Zhou, \& Xiao, 2020). It is expected that within a short period students will get familiarity with technological use and it would be a great step towards academic growth.

\section{Conclusion}

The risk of COVID-19 is associated with many psychological or mental health issues among children. Currently, the severity of COVID-19 has decreased, but fear of the other wave of COVD-19 is prevailing. Hence the online psychotherapy and psychiatric services must be intact for the students. Furthermore, as the effects of the pandemic are disseminated even after the pandemic, psychologists, psychiatrists, and mental health practitioners must provide their services to manage student's problem. In addition, as the pandemic has imposed restrictions on research and many interesting research questions considering child populations have been emerged. Therefore the prevalence studies in diverse cities of Pakistan must be conducted to investigate the ratio of mental health issues.

\section{Recommendations}

The current study has some recommendations.

1. As the current study is qualitative in nature: more quantitative studies should be carried out to investigate the student's reaction for retrieving valid and reliable results.

2. The current study primarily focuses on the initial phase of COVID-19: future studies should be carried out to investigate the student's reaction during other phases of COVID-19.

3. The current study has been carried out on small sample size: upcoming researches should be carried out on a large sample size to generalize the findings. 


\section{References}

Bontcheva, K. Gorrell, G. \& Wessels, B. (2013). Social Media and Information Overload: Cornell University Library: Survey Results. arXiv e-prints.

Brooks, S. K. Webster, R. K. Smith, L. E. Woodland, L. Wessely, S. Greenberg, N. \& Rubin, G. J. (2020). The psychological impact of quarantine and how to reduce it: rapid review of the evidence. Lancet, 14; 395(10227):912-920. doi: 10.1016/S01406736(20)30460-8.

Chatterjee, K. \& Chauhan, V. S. (2020). Epidemics, quarantine and mental health. Medical Journal, Armed Forces India, 76(2). Doi10.1016/j.mjafi.2020.03.017.

Chiodini J. (2020). Online learning in the time of COVID-19. Travel medicine and infectious disease, 34, 101669. https:/ / doi.org/10.1016/j.tmaid.2020.101669

Fiorillo, A. \& Gorwood, P. (2020). The consequences of the COVID-19 pandemic on mental health and implications for clinical practice. European psychiatry: the journal of the Association of European Psychiatrists, 63(1), e32. https://doi.org/10.1192/j.eurpsy.2020.35

Gao, J. Zheng, P. Jia, Y. Chen, H. Mao, Y. Chen, S. Wang, Y. Fu, H. \& Dai, J. (2020). Mental health problems and social media exposure during COVID-19 outbreak. PloS One, 15(4), e0231924. https://doi.org/10.1371/journal.pone.0231924

Huremovic, D. (2019). Psychiatry of pandemic: A mental health response to infection outbreak. North Shore University Hospital: Manhasset: NY, USA.

Keles, B. McCrea, N. Grealish, A. A systematic review: the influence of social media on depression, anxiety and psychological distress in adolescents. International Journal of Adolescents and Youth: 25(1);79-93.

Khan, S. Khan, M. Maqsood, K. Hussain, T. Noor-Ul-Huda, \& Zeeshan, M. (2020). Is Pakistan prepared for the COVID-19 epidemic? A questionnaire-based survey. Journal of medical virology, 92(7), 824-832. https://doi.org/10.1002/jmv.25814

Li, H. Liu, S. M. Yu, X. H. Tang, S. L. \& Tang, C. K. (2020). Coronavirus disease 2019 (COVID-19): current status and future perspectives. International Journal of Antimicrobial Agents, 55(5), https:// doi.org/10.1016/j.ijantimicag.2020.105951

105951.

Li, S. Wang, Y. Xue, J. Zhao, N. \& Zhu, T. (2020). The Impact of COVID-19 Epidemic Declaration on Psychological Consequences: A Study on Active Weibo 
Users. International Journal of Environmental Research and Public Health, 17(6), 2032. https://doi.org/10.3390/ijerph17062032

Mukhtar S. (2021). Preparedness and proactive infection control measures of Pakistan during COVID-19 pandemic outbreak. Research in Social $\mathcal{E}$ Administrative Pharmacy: RSAP, 17(1), 2052. https:// doi.org/10.1016/j.sapharm.2020.04.011

Rehman, S. \& Lela, U. (2020). Psychological Aid to COVID-19 Pandemic: A Mental Health Response to Crises Management. Psychiatria Danubina, 32(2), 262-265. https://doi.org/10.24869/psyd.2020.262

Rehman, S. Muzammil, A. \& Lela, U. (2020). The New World 2020: A Crucial Paradigm for Meeting Fast Changing World Demands in Pakistan after COVID19 Outbreak. Psychiatria Danubina, 32(3-4), 458-462. https:// doi.org/10.24869/psyd.2020.458

Rehman, S. \& Lela, U. (2021). Pharmacological treatment during CoViD-19 and mental health issues. Rivista di psichiatria, 56(1), 53-55. https://doi.org/10.1708/3546.35221

Shigemura, J. Ursano, R. J. Morganstein, J. C. Kurosawa, M. \&Benedek, D. M. (2020). Public responses to the novel 2019 coronavirus (2019-nCoV) in Japan: Mental health consequences and target populations. Psychiatry and Clinical Neurosciences, 74(4), 281-282. https://doi.org/10.1111/pcn.12988

Waris, A. Atta, U. K. Ali, M. Asmat, A. \&Baset, A. (2020). COVID-19 outbreak: current scenario of Pakistan. New Microbes and New Infections, 35, 100681. https:// doi.org/10.1016/j.nmni.2020.100681

Zhou, T. Huang, S. Cheng, J. \& Xiao, Y. (2020). The Distance Teaching Practice of Combined Mode of Massive Open Online Course Micro-Video for Interns in Emergency Department During the COVID-19 Epidemic Period. Telemedicine Journal and e-health: the Official Journal of the American Telemedicine Association, 26(5), 584-588. https:// doi.org/10.1089/tmj.2020.0079 